This item was submitted to Loughborough's Research Repository by the author.

Items in Figshare are protected by copyright, with all rights reserved, unless otherwise indicated.

\title{
Book Review: Alan Tomlinson, FIFA (Federation Internationale de Football Association): The Men, The Myths and The Money
}

\section{PLEASE CITE THE PUBLISHED VERSION}

http://dx.doi.org/10.1177/0038038515583766

\section{PUBLISHER}

(C) The Author. Published by Sage

\section{VERSION}

AM (Accepted Manuscript)

\section{PUBLISHER STATEMENT}

This work is made available according to the conditions of the Creative Commons Attribution-NonCommercialNoDerivatives 4.0 International (CC BY-NC-ND 4.0) licence. Full details of this licence are available at: https://creativecommons.org/licenses/by-nc-nd/4.0/

\section{LICENCE}

CC BY-NC-ND 4.0

\section{REPOSITORY RECORD}

Brannagan, Paul M.. 2019. "Book Review: Alan Tomlinson, FIFA (federation Internationale De Football Association): The Men, the Myths and the Money". figshare. https://hdl.handle.net/2134/20859. 
Alan Tomlinson

\section{FIFA (Fédération Internationale de Football Association): The Men, The Myths and The Money}

Abingdon: Routledge, 2014, £26.99 pbk, (ISBN: 9780415498319), 196pp.

Reviewed by: Paul Michael Brannagan, Loughborough University, UK

It was the fifth President of the International Olympic Committee, Avery Brundage, who once remarked how politics and sport had little to do with one another. If only he was alive today, what might he think of the recent revelations surrounding football's world governing body, the Fédération Internationale de Football Association (FIFA)? Perhaps his first area of inquisitiveness might be to pinpoint how the organization that started out with only seven members has become the truly global economic, political and cultural brand we all know today. His second point of interest would surely, however, question how, throughout its unprecedented growth, FIFA's various presidents, members and associates have managed to operate for so long within the continual pool of controversy and pessimism that global football governance habitually withstands.

In looking to fulfil curiosity of this kind, Alan Tomlinson's book, FIFA: The Men, The Myths and The Money, endeavours to chart the historical roots and evolution of FIFA, adding decisive socio-political insight along the way. Having discussed why a book of this nature is necessary in his Introduction, Tomlinson organizes the remainder of his text into nine core chapters. Chapter 1, 'Origins', traces FIFA's development since it was founded in 1904, during a time when, via its unique ability to conjure notions related to national sentiment, football become a fundamental $\operatorname{cog}$ in the making of modern societies - particularly through its unique aptitude to simultaneously showcase national distinctiveness and cultural superiority. Chapter 2, 'Workings', adds crucial insight into the way FIFA has traditionally conducted its business through critically evaluating the organization's overall mission, rationale and membership, as well as its administrative structure and processes. Chapter 3, 'Leaders', focuses on the men of FIFA and, in particular, the various values they have stood for. Here, Tomlinson concentrates on Jules Rimet, Stanley Rous and João Havelange, detailing how the former truly internationalized FIFA, whilst the latter became the driving force behind the organization's most expansive commercial and professional phase. Chapter 4, 'The Supreme Leader', looks at the eighth FIFA President, Joseph 'Sepp' Blatter. Noting how Blatter has been part of FIFA for over one third of a century, the chapter comments on his presidential survival strategies, documenting how he neutralized his early opponents through the expansion of the Executive Committee, his understating that at least most of the 148 FIFA Members need some form of 'hand-out', and his ability to work behind the gaze of UEFA and 'soften' various opponents with charm and appeal - all leading, of course, to him receiving the highest number of votes for any president in his 2011 election.

Having provided the reader with an historical account of FIFA, its expansion, mission, values and presidents, Chapter 5, 'Money-spinners', maps sport's overall relationship with the global media and mass-consumer market, resulting in football becoming an immensely sought-after commodity for a plethora of stakeholders. Leading directly on from this, Chapter 6, 'Cash Cow', focuses on the Men's World Cup, and its significant economic growth. Taking the reader on a journey from Mexico 1986 to Russia 2018, Tomlinson shows how the FIFA 'brand' has become a commercial phenomenon on a truly universal scale, leading to the Men's World Cup being staged in large part for the 
metropolitan elite and global consumer culture - the consequences of this played out, of course, in the plethora of protests leading up to Brazil 2014.

Chapter 7, 'Crises', focuses on the multiplicity of high-profile corruption and controversial allegations FIFA has endured in the 21st century in regard to a lack of credibility, questionable leadership styles, and abuse of decision-making power. Directly leading on from this, Chapter 8, 'Futures', focuses on the so-called 'promises' made by FIFA in regard to organizational reform. Here, Tomlinson pinpoints the various club, sponsor and nation-state interests involved in FIFA, concluding that, when all is said and done, the organization essentially has the capacity to resist any form of radical change, continuing - as it does - to sit beyond the relative reach of any effective legal body in relation to its wider remit. Finally, in Chapter 9, 'Conclusion', Tomlinson signs off by locating some of the central points/recurrent themes discussed throughout the book. In doing so, Tomlinson offers the reader a theoretical and interpretive explanation of FIFA by drawing on the work of leading academics from various fields, such as the economist, Albert O. Hirschman, and the international relations scholar, Susan Strange.

Overall, Tomlinson's book offers a welcome addition to the study of sport. Not only does it provide readers with a great insight into the development, values, personnel and controversy surrounding football's world governing body, but it also adds to the literature on sport politics and the sociology of sport. I would, therefore, recommend this book to those studying and/or teaching in the field of sport studies, and also to those who simply have a general interest in sport.

\section{(ORIGINAL MANUSCRIPT)}

This is the Authors' Original Manuscript in its final and definitive form. The Version of Record can be found via the following reference:

Brannagan, P. M. (2015). Book Review: Alan Tomlinson, FIFA (Fédération

Internationale de Football Association): The Men, The Myths and The Money, Sociology.

Available at:

http://soc.sagepub.com/content/early/2015/05/29/0038038515583766.extract 